\title{
Comparison of Radioiodine- or Radiobromine-Labeled RGD Peptides between Direct and Indirect Labeling Methods
}

\author{
Kazuma Ogawa, ${ }^{* a, b}$ Takuya Takeda, ${ }^{b}$ Masaru Yokokawa, ${ }^{b}$ Jing Yu, ${ }^{b}$ Akira Makino, ${ }^{c}$ \\ Yasushi Kiyono, ${ }^{c}$ Kazuhiro Shiba, ${ }^{d}$ Seigo Kinuya, ${ }^{b}$ and Akira Odani ${ }^{b}$ \\ ${ }^{a}$ Institute for Frontier Science Initiative, Kanazawa University; Kanazawa, Ishikawa 920-1192, Japan: ${ }^{b}$ Graduate \\ School of Medical Sciences, Kanazawa University; Kanazawa, Ishikawa 920-1192, Japan: ${ }^{\circ}$ Biomedical Imaging \\ Research Center, University of Fukui; Yoshida, Fukui 910-1193, Japan: and ${ }^{d}$ Advanced Science Research Center, \\ Kanazawa University; Kanazawa, Ishikawa 920-8640, Japan.
}

Received February 2, 2018; accepted March 22, 2018

Radiolabeled cyclic peptides containing the (Arg-Gly-Asp) RGD sequence for use in positron emission tomography (PET) imaging, single-photon emission computed tomography (SPECT) imaging, and targeted radionuclide therapy of cancer have been reported. In this study, RGD was used as a model carrier peptide for diagnosis and therapy of cancer. To evaluate the characteristics of radiohalogen-labeled peptides, several kinds of labeled RGD peptides $\left[{ }^{125} \mathrm{I}-\mathrm{c}(\mathrm{RGDyK}),{ }^{77} \mathrm{Br}\right.$-c(RGDyK), $\left[{ }^{125} \mathrm{I}\right] \mathrm{SIB}-\mathrm{c}(\mathrm{RGDfK}),\left[{ }^{77} \mathrm{Br}\right] \mathrm{SBrB}-\mathrm{c}(\mathrm{RGDfK})$, $\left[{ }^{125} \mathrm{I}\right] \mathrm{SIB}-\mathrm{EG}_{2}-\mathrm{c}(\mathrm{RGDfK})$, and $\left.\left.{ }^{77} \mathrm{Br}\right] \mathrm{SBrB}_{-E_{2}}-\mathrm{c}(\mathrm{RGDfK})\right]$ were designed, prepared, and evaluated. In these initial studies, ${ }^{77} \mathrm{Br}\left(t_{1 / 2}=57.0 \mathrm{~h}\right)$ and ${ }^{125} \mathrm{I}\left(t_{1 / 2}=59.4 \mathrm{~d}\right)$ were used because of their longer half-lives. Precursor peptides were synthesized using a standard 9-fluorenylmethyloxycarbonyl (Fmoc)-based solid-phase methodology. Radiolabeled peptides were prepared by chloramine-T method or conjugation of RGD peptides with $\left[{ }^{125} \mathrm{I}\right] N$ succinimidyl 3-iodobenzoate $\left(\left[{ }^{125} \mathrm{I}\right] \mathrm{SIB}\right)$ or $\left[{ }^{77} \mathrm{Br}\right] N$-succinimidyl 3-bromobenzoate $\left(\left[{ }^{77} \mathrm{Br}\right] \mathrm{SBrB}\right)$. Measurement of the partition coefficients, integrin binding assay, and biodistribution experiments in tumor-bearing mice were performed. ${ }^{125} \mathrm{I}$ and ${ }^{77} \mathrm{Br}$ labeling were successfully performed using similar methods, and in vitro characteristics and biodistributions were similar between the ${ }^{125} \mathrm{I}$-labeled and corresponding ${ }^{77} \mathrm{Br}$-labeled peptides. $\left[{ }^{125} \mathrm{I}\right] \mathrm{SIB}$ - and $\left.{ }^{77} \mathrm{Br}\right] \mathrm{SBrB}$-conjugated RGD peptides showed higher partition coefficients, lower tumor uptakes, and higher intestinal uptake than ${ }^{125} \mathrm{I}-\mathrm{c}(\mathrm{RGDyK})$ and ${ }^{77} \mathrm{Br}-\mathrm{c}(\mathrm{RGDyK}) .\left[{ }^{125} \mathrm{I}\right] \mathrm{SIB}-\mathrm{EG}_{2}$-c(RGDfK) and $\left.{ }^{77} \mathrm{Br}\right] \mathrm{SBrB}-\mathrm{EG}_{2}-\mathrm{c}(\mathrm{RGDfK})$, which possess an ethylene glycol linker, decreased lipophilicity and uptake in intestine compared with $\left[{ }^{125} \mathrm{I}\right] \mathrm{SIB}-\mathrm{c}(\mathrm{RGDfK})$ and $\left[{ }^{77} \mathrm{Br}\right] \mathrm{SBrB}-\mathrm{c}(\mathrm{RGDfK})$, which possess no linker. However, the improvement in biodistribution of $\left[{ }^{125} \mathrm{I}\right] \mathrm{SIB}-\mathrm{EG}_{2}-\mathrm{c}(\mathrm{RGDfK})$ and $\left[{ }^{77} \mathrm{Br}\right] \mathrm{SBrB}_{-\mathrm{EG}}$-c(RGDfK)] was insufficient. In conclusion, directly radiohalogenated $c(R G D y K)$ peptides are potentially more useful for tumor imaging and therapy than indirectly radiohalogenated ones.

Key words Arg-Gly-Asp (RGD) peptide; integrin; tumor; radiobromine; positron emission tomography (PET)

Some pathological processes such as tumor development are related to angiogenesis. Integrin molecules are heterodimeric transmembrane receptors for cell adhesion, and it has been reported that $\alpha_{\mathrm{v}} \beta_{3}$ integrin is a representative subtype characterized as a regulator of angiogenesis. ${ }^{1)}$ Therefore, the $\alpha_{\mathrm{v}} \beta_{3}$ integrin has been identified as a marker of angiogenic blood vessels. ${ }^{2)}$ Moreover, it is known that $\alpha_{\mathrm{v}} \beta_{3}$ integrin expression is upregulated on endothelial cells during neovascularization associated with solid tumors, ${ }^{3)}$ and $\alpha_{\mathrm{v}} \beta_{3}$ integrin is overexpressed in some kinds of cancer cells, but less expressed in normal organs. ${ }^{4)}$ Therefore, $\alpha_{\mathrm{v}} \beta_{3}$ integrin has garnered much interest as an important target for imaging and therapy of cancer in nuclear medicine. ${ }^{5)}$ Ligands that have a high affinity for $\alpha_{\mathrm{v}} \beta_{3}$ integrin have been investigated and developed. ${ }^{6)}$ As the most typical ligand for the $\alpha_{\mathrm{v}} \beta_{3}$ integrin, cyclic peptides containing Arg-Gly-Asp (RGD) sequence have been investigated because of their high affinity for $\alpha_{\mathrm{v}} \beta_{3}$ integrin. ${ }^{7)}$ A number of radiolabeled RGD peptide derivatives for use in positron emission tomography (PET) imaging, single-photon emission computed tomography (SPECT) imaging, and targeted radionuclide therapy have been reported. ${ }^{8-13)}$

Among the halogens, many useful radioisotopes for nuclear medicine and life sciences exist, such as ${ }^{18} \mathrm{~F}$ (for PET), ${ }^{76} \mathrm{Br}$ (for PET), ${ }^{77} \mathrm{Br}$ (for basic research or Auger therapy), ${ }^{123} \mathrm{I}$ (for SPECT), ${ }^{124} \mathrm{I}$ (for PET), ${ }^{125} \mathrm{I}$ (for basic research or Auger therapy), ${ }^{131} \mathrm{I}$ (for $\beta^{-}$therapy), and ${ }^{211} \mathrm{At}$ (for $\alpha$ therapy). ${ }^{14)} \mathrm{A}$ labeling method for proteins that uses radioiodine and an oxidation agent, such as chloramine-T, has been used classically. The chloramine-T method can effectively and easily introduce radioiodine into tyrosine residue in proteins. Moreover, the chloramine-T method can be adapted for peptides with a tyrosine residue and small molecules containing a phenolic group. ${ }^{15,16)}$ Another representative labeling approach that uses radioiodine is a method using an iododestannylation reaction from a corresponding precursor with a trialkylstannyl group. This method has been widely used for radioiodination of small molecules ${ }^{17)}$ or indirect labeling. One of the reagents for indirect labeling with radioiodine is $N$-succinimidyl 3-(tri- $n$ butylstannyl)benzoate (ATE), which has been used for radiolabeling of proteins, such as antibodies. ${ }^{18,19)}$ The tri- $n$-butylstannyl group in ATE could be easily substituted by radioiodine. In the case of preparing radiolabeled proteins or peptides, $\left[{ }^{125} \mathrm{I}\right] N$-succinimidyl 3 -iodobenzoate $\left(\left[{ }^{125} \mathrm{I}\right] \mathrm{SIB}\right)$ is prepared by the iododestannylation reaction following conjugation with proteins or peptides.

Labeling with radiofluorine normally requires different methods of radioiodine labeling due to distinct physical properties of fluorine. ${ }^{20)}$ The same methodology for radioiodine 


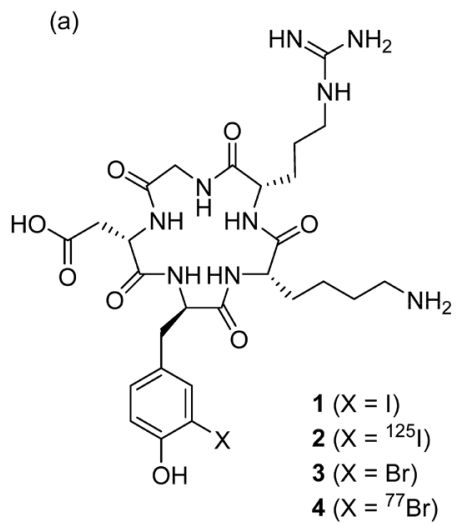

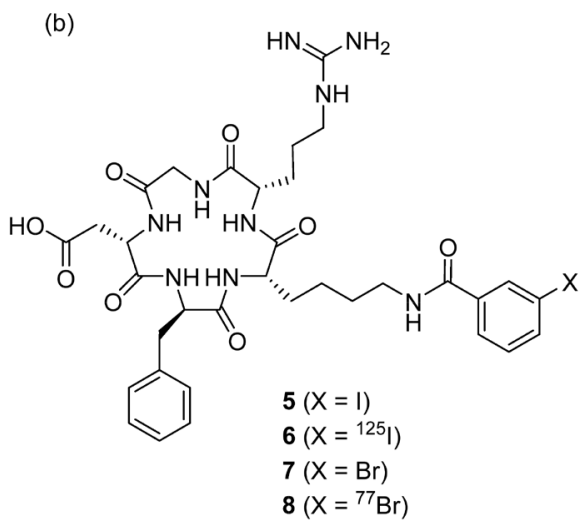

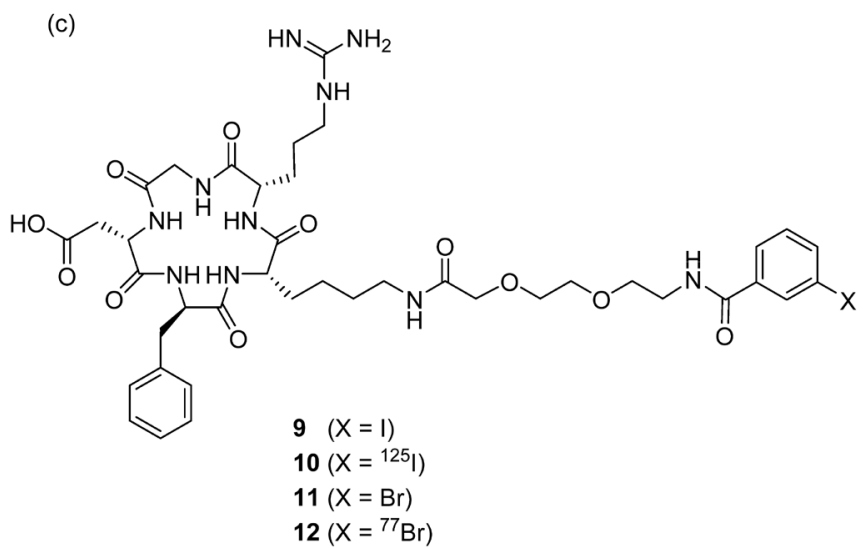

Fig. 1. Structures of Iodinated and Brominated RGD Peptides (a) I-c(RGDyK) and Br-c(RGDyK), (b) SIB-c(RGDfK) and SBrB-c(RGDfK), (c) SIB$\mathrm{EG}_{2}-\mathrm{c}(\mathrm{RGDfK})$ and $\mathrm{SBrB}-\mathrm{EG}_{2}-\mathrm{c}(\mathrm{RGDfK})$

labeling could be used for labeling with radiobromine ${ }^{21)}$ : introduction of a radiobromine molecule at the next position of a hydroxyl group in a phenolic group using an oxidation agent, such as chloramine-T, and introduction of a radiobromine molecule at any position of the benzene ring using a bromodestannylation reaction from corresponding precursor with a trialkylstannyl group, such as $\left[{ }^{77} \mathrm{Br}\right] \mathrm{N}$-succinimidyl 3-bromobenzoate $\left.\left({ }^{77} \mathrm{Br}\right] \mathrm{SBrB}\right)$ from ATE.

In this study, RGD peptide was used as a model peptide and a carrier for diagnosis and therapy of cancer. We designed, prepared, and evaluated in vitro and in vivo several types of directly and indirectly labeled RGD peptides for evaluating characteristics between radioiodine- and radiobrominelabeled peptides (Fig. 1; ${ }^{125} \mathrm{I}-\mathrm{c}(\mathrm{RGDyK})(2),{ }^{77} \mathrm{Br}-\mathrm{c}$ (RGDyK) (4), $\left[{ }^{125} \mathrm{I}\right] \mathrm{SIB}-\mathrm{c}(\mathrm{RGDfK}) \quad$ (6), $\quad\left[{ }^{77} \mathrm{Br}\right] \mathrm{SBrB}-\mathrm{c}(\mathrm{RGDfK}) \quad$ (8), $\left.{ }^{125} \mathrm{I}\right] \mathrm{SIB}-\mathrm{EG}_{2}-\mathrm{c}(\mathrm{RGDfK})(\mathbf{1 0})$, and $\left.{ }^{77} \mathrm{Br}\right] \mathrm{SBrB}-\mathrm{EG}_{2}-\mathrm{c}$ (RGDfK) (12)) and for applying to astatine-labeled peptides in the future regarding labeling methods, physical characteristics, and radionuclides. Although we are interested in developing ${ }^{76} \mathrm{Br}-$ $\left(t_{1 / 2}=16.2 \mathrm{~h}\right),{ }^{123} \mathrm{I}-\left(t_{1 / 2}=13.2 \mathrm{~h}\right),{ }^{124} \mathrm{I}-\left(t_{1 / 2}=4.2 \mathrm{~d}\right)$, or ${ }^{131} \mathrm{I}-\left(t_{1 / 2}=8.0 \mathrm{~d}\right)$ labeled RGD peptides for $\alpha_{\mathrm{v}} \beta_{3}$ integrin receptor SPECT $\left.{ }^{123} \mathrm{I}\right)$ or PET $\left({ }^{76} \mathrm{Br}\right.$ and $\left.{ }^{124} \mathrm{I}\right)$ imaging and targeted radionuclide therapy $\left({ }^{131} \mathrm{I}\right)$, in this study, ${ }^{77} \mathrm{Br}\left(t_{1 / 2}=57.0 \mathrm{~h}\right)$ and ${ }^{125} \mathrm{I}\left(t_{1 / 2}=59.4 \mathrm{~d}\right)$ were used as alternative radionuclides because of their longer half-lives.

\section{Results and Discussion}

Preparation of Radiolabeled RGD Peptides In this study, the preparation of radioiodinated and radiobrominated pep- tides were performed using the same precursors and the similar procedure. Namely, ${ }^{125} \mathrm{I}-\mathrm{c}$ (RGDyK) (2) and ${ }^{77} \mathrm{Br}-\mathrm{c}(\mathrm{RGDyK})$ (4) were prepared by the introduction of radioisotopes into the tyrosine residue of $\mathrm{c}(\mathrm{RGDyK})$, which was prepared using standard 9-fluorenylmethyloxycarbonyl (Fmoc)-based solidphase methodology, using the chloramine-T method under nocarrier-added conditions with high radiochemical yields (89 and $73 \%$, respectively). However, radiochemical yields of indirect labeling using standard electrophilic halogenation of the tri- $n$-butylstannyl group of ATE and following conjugation of RGD peptides with $\left[{ }^{125} \mathrm{I}\right] \mathrm{SIB}$ or $\left[{ }^{77} \mathrm{Br}\right] \mathrm{SBrB}$ were low as $30 \%$ for $\left[{ }^{125} \mathrm{I}\right] \mathrm{SIB}-\mathrm{c}$ (RGDfK) $(6), 25 \%$ for $\left[{ }^{77} \mathrm{Br}\right] \mathrm{SBrB}-\mathrm{c}(\mathrm{RGDfK})$ (8), $34 \%$ for $\left[{ }^{125} \mathrm{I}\right] \mathrm{SIB}-\mathrm{EG}_{2}-\mathrm{c}$ (RGDfK) (10), and $22 \%$ for $\left[{ }^{77} \mathrm{Br}\right] \mathrm{SBrB}-\mathrm{EG}_{2}-\mathrm{c}(\mathrm{RGDfK})$ (12). These results reflected the low yields of the conjugation of c(RGDfK) peptides with $\left.{ }^{[25} \mathrm{I}\right] \mathrm{SIB}$ or $\left.{ }^{77} \mathrm{Br}\right] \mathrm{SBrB}$ because, in part, the active ester in $\left[{ }^{125} \mathrm{I}\right] \mathrm{SIB}$ or $\left[{ }^{77} \mathrm{Br}\right] \mathrm{SBrB}$ could be hydrolyzed to the carboxyl group, and a twice purification HPLC procedure was necessary. The radiochemical yields of $\left[{ }^{125} \mathrm{I}\right] \mathrm{SIB}$ and $\left[{ }^{77} \mathrm{Br}\right] \mathrm{SBrB}$ were 65 and $53 \%$, respectively. These results suggested that the radiochemical yields of the radiobrominations were a little lower than those of radioiodinations, which is consistent with the results from our previous studies of radiobromination and radioiodination performed using the same precursor. ${ }^{17,22)}$

All compounds showed radiochemical purities $>95 \%$ after purification by reversed phase (RP)-HPLC. The identities of radiolabeled peptides were verified by comparing the retention times of the corresponding peptides with those of nonradioactive iodine or bromine. 
Table 1. Partition Coefficients of $\left.{ }^{125} \mathrm{I}-\mathrm{c}(\mathrm{RGDyK}),{ }^{77} \mathrm{Br}-\mathrm{c}(\mathrm{RGDyK}),{ }^{125} \mathrm{I}\right]$ SIB-c(RGDfK), $\quad\left[{ }^{77} \mathrm{Br}\right] \mathrm{SBrB}-\mathrm{c}(\mathrm{RGDfK}), \quad\left[{ }^{125} \mathrm{I}\right] \mathrm{SIB}^{-E_{2}}-\mathrm{c}(\mathrm{RGDfK}), \quad$ and $\left[{ }^{77} \mathrm{Br}\right] \mathrm{SBrB}-\mathrm{EG}_{2}-\mathrm{c}(\mathrm{RGDfK})$

\begin{tabular}{lll}
\hline \hline & $C \log P$ & $\log P$ value \\
\hline${ }^{125} \mathrm{I}-\mathrm{c}(\mathrm{RGDyK})$ & -3.19 & $-2.98 \pm 0.03$ \\
${ }^{77} \mathrm{Br}-\mathrm{c}(\mathrm{RGDyK})$ & -3.38 & $-3.19 \pm 0.04$ \\
{$\left[{ }^{125} \mathrm{I}\right] \mathrm{SIB}-\mathrm{c}(\mathrm{RGDfK})$} & -0.74 & $-0.14 \pm 0.04$ \\
{$\left[{ }^{77} \mathrm{Br}\right] \mathrm{SBrB}-\mathrm{c}(\mathrm{RGDfK})$} & -1.00 & $-0.32 \pm 0.00$ \\
{$\left[{ }^{125} \mathrm{I}\right] \mathrm{SIB}-\mathrm{EG}_{2}-\mathrm{c}(\mathrm{RGDfK})$} & -1.71 & $-0.91 \pm 0.01$ \\
{$\left[{ }^{77} \mathrm{Br}\right] \mathrm{SBrB}_{-}-\mathrm{EG}_{2}-\mathrm{c}(\mathrm{RGDfK})$} & -1.97 & $-1.15 \pm 0.02$ \\
\hline Each $\log P$ value is $\log [$ radioactivity in 1-octanol/radioactivity in $0.1 \mathrm{M}$ phosphate \\
buffer (pH 7.4)]. Mean \pm standard deviation (S.D.) for three or four experiments.
\end{tabular}

Table 2. $\mathrm{IC}_{50}$ Values of I-c(RGDyK), Br-c(RGDyK), SIB-c(RGDfK), SBrB-c(RGDfK), SIB-EG ${ }_{2}-\mathrm{c}(\mathrm{RGDfK})$, and $\mathrm{SBrB}-\mathrm{EG}_{2}-\mathrm{c}(\mathrm{RGDfK})$

\begin{tabular}{ll}
\hline \hline & $\mathrm{IC}_{50}(\mathrm{~nm})$ \\
\hline $\mathrm{I}-\mathrm{c}($ RGDyK$)$ & $16.6 \pm 9.9$ \\
Br-c(RGDyK) & $33.5 \pm 8.8$ \\
SIB-c(RGDfK) & $22.1 \pm 13.3$ \\
SBrB-c(RGDfK) & $54.1 \pm 13.3$ \\
SIB-EG 2 -c(RGDfK) & $41.2 \pm 14.2$ \\
SBrB-EG $_{2}$-c(RGDfK) & $50.5 \pm 17.4$ \\
\hline
\end{tabular}

Each $\mathrm{IC}_{50}$ value is shown as mean \pm S.D. for three experiments.

Determination of Partition Coefficient The results of measuring the partition coefficients as the $\log P$ values of $\quad{ }^{125} \mathrm{I}-\mathrm{c}(\mathrm{RGDyK}), \quad{ }^{77} \mathrm{Br}-\mathrm{c}(\mathrm{RGDyK}), \quad\left[{ }^{125} \mathrm{I}\right] \mathrm{SIB}-\mathrm{c}(\mathrm{RGDfK})$, $\left[{ }^{77} \mathrm{Br}\right] \mathrm{SBrB}-\mathrm{c}(\mathrm{RGDfK}), \quad\left[{ }^{125} \mathrm{I}\right] \mathrm{SIB}-\mathrm{EG}_{2}-\mathrm{c}(\mathrm{RGDfK}), \quad$ and $\left[{ }^{77} \mathrm{Br}\right] \mathrm{SBrB}-\mathrm{EG}_{2}-\mathrm{c}(\mathrm{RGDfK})$ are listed in Table 1. $C \log P$ values calculated using ChemBioDraw Ultra software version 14.0 (Cambridge Soft Corporation, Cambridge, MA, U.S.A.) are also listed in Table 1. The tendencies of these values were consistent between the measured $\log P$ values and $C \log P$ values. The directly labeled RGD peptides, ${ }^{125} \mathrm{I}-\mathrm{c}(\mathrm{RGDyK})$ and ${ }^{77} \mathrm{Br}-\mathrm{c}(\mathrm{RGDyK})$, showed much higher hydrophilicity than $\left[{ }^{125} \mathrm{I}\right] \mathrm{SIB}$ or $\left[{ }^{77} \mathrm{Br}\right] \mathrm{SBrB}$ conjugated RGD peptides, $\left[{ }^{125} \mathrm{I}\right] \mathrm{SIB}-\mathrm{c}(\mathrm{RGDfK}), \quad\left[{ }^{77} \mathrm{Br}\right] \mathrm{SBrB}-\mathrm{c}(\mathrm{RGDfK})$, $\left[{ }^{125} \mathrm{I}\right] \mathrm{SIB}-\mathrm{EG}_{2}-\mathrm{c}(\mathrm{RGDfK})$, and $\left[{ }^{77} \mathrm{Br}\right] \mathrm{SBrB}-\mathrm{EG}_{2}-\mathrm{c}(\mathrm{RGDfK})$. As expected, $\left[{ }^{125} \mathrm{I}\right] \mathrm{SIB}-\mathrm{EG}_{2}-\mathrm{c}(\mathrm{RGDfK})$ and $\left[{ }^{77} \mathrm{Br}\right] \mathrm{SBrB}-$ $\mathrm{EG}_{2}-\mathrm{c}(\mathrm{RGDfK})$ with an ethylene glycol chain as a hydrophilic linker showed higher hydrophilicity than $\left[{ }^{125} \mathrm{I}\right] \mathrm{SIB}-\mathrm{c}(\mathrm{RGDfK})$ and $\left[{ }^{77} \mathrm{Br}\right] \mathrm{SBrB}-\mathrm{c}(\mathrm{RGDfK})$ without a linker. Bromine-labeled peptides showed a little $\operatorname{lower} \log P$ values than iodine labeled peptides. HPLC analyses also supported these results, because the retention times of the bromine-labeled peptides were a little shorter than those of the corresponding iodine-labeled peptides.

$\boldsymbol{\alpha}_{\mathrm{v}} \boldsymbol{\beta}_{\mathbf{3}}$ Integrin Binding Assay The affinities of $\mathrm{Br}-$ c(RGDyK), I-c(RGDyK), SBrB-c(RGDfK), SIB-c(RGDfK) SBrB-c(RGDfK), and SIB-EG ${ }_{2}-\mathrm{c}(\mathrm{RGDfK})$ for the $\alpha_{\mathrm{v}} \beta_{3}$ integrin were determined by performing competitive binding assays. The typical results of these assays are shown in Fig. 2 and are summarized in Table 2. Binding of ${ }^{125} \mathrm{I}-\mathrm{c}(\mathrm{RGDyK})$ to $\alpha_{\mathrm{v}} \beta_{3}$ integrin was competed by each RGD peptide in a concentration-dependent manner. Because these values were similar (statistically not significant using Tukey-Kramer test), the SIB unit or SBrB unit and ethylene glycol linker did not significantly impede the affinity of RGD peptide for $\alpha_{\mathrm{v}} \beta_{3}$ integrin.

Animal Experiments In this study, ${ }^{125} \mathrm{I}-\mathrm{c}(\mathrm{RGDyK})$

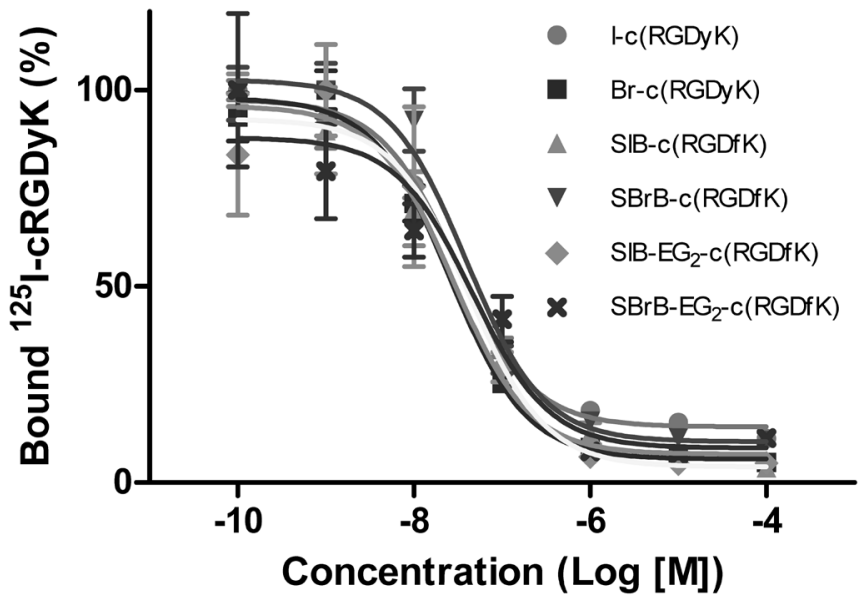

Fig. 2. Typical Displacement Curves of Competition Binding Assay to the $\alpha_{\mathrm{v}} \beta_{3}$ Integrin of ${ }^{125} \mathrm{I}-\mathrm{c}(\mathrm{RGDyK})$ with I-c(RGDyK), Br-c(RGDyK), SIB-c(RGDfK), SBrB-c(RGDfK), SIB-EG ${ }_{2}-\mathrm{c}(\mathrm{RGDfK})$, and SBrB-EG ${ }_{2}-$ c(RGDfK)

and ${ }^{77} \mathrm{Br}-\mathrm{c}(\mathrm{RGDyK}), \quad\left[{ }^{125} \mathrm{I}\right] \mathrm{SIB}-\mathrm{c}(\mathrm{RGDfK})$ and $\left[{ }^{77} \mathrm{Br}\right] \mathrm{SBrB}-$ $\mathrm{c}(\mathrm{RGDfK})$, or $\left[{ }^{125} \mathrm{I}\right] \mathrm{SIB}-\mathrm{EG}_{2}-\mathrm{c}(\mathrm{RGDfK})$ and $\left[{ }^{77} \mathrm{Br}\right] \mathrm{SBrB}-\mathrm{EG}_{2}-$ $\mathrm{c}(\mathrm{RGDfK})$ were co-injected into tumor-bearing mice to minimize the number of mice and experimental errors. The results of biodistribution experiments of radiolabeled RGD peptides in U87MG tumor-bearing mice are shown in Tables 3-5. It has been known that iodine anion accumulates in the thyroid and stomach. Therefore, the uptakes in thyroid and stomach have been used as indexes of deiodination of radioiodine-labeled tracers in vivo. In this study, the accumulation in the stomach was not high for all radioiodine-labeled RGD peptides, which suggested that significant deiodination did not occur in vivo. The biodistribution of ${ }^{125} \mathrm{I}-\mathrm{c}(\mathrm{RGDyK})$ and ${ }^{77} \mathrm{Br}-\mathrm{c}(\mathrm{RGDyK})$ showed similar patterns, such as high tumor uptake based on the affinity of RGD motif for the $\alpha_{\mathrm{v}} \beta_{3}$ integrin and low uptake in non-target tissues except kidney as a tissue for excretion.

In addition, the biodistribution of $\left[{ }^{125} \mathrm{I}\right] \mathrm{SIB}-\mathrm{c}(\mathrm{RGDfK})$ and $\left[{ }^{77} \mathrm{Br}\right] \mathrm{SBrB}-\mathrm{c}(\mathrm{RGDfK})$ demonstrated similar patterns; particularly, extremely higher accumulation in the small intestine and lower accumulation in the kidney and tumor than those of ${ }^{125} \mathrm{I}-\mathrm{c}(\mathrm{RGDyK})$ and ${ }^{77} \mathrm{Br}-\mathrm{c}(\mathrm{RGDyK})$. The extremely higher accumulation in the intestine and lower accumulation in tumors of $\left[{ }^{125} \mathrm{I}\right] \mathrm{SIB}-\mathrm{c}(\mathrm{RGDfK})$ and $\left[{ }^{77} \mathrm{Br}\right] \mathrm{SBrB}-\mathrm{c}(\mathrm{RGDfK})$ were not predicted. Especially, the same degree of tumor accumulation was predicted because the affinity of SIB-c(RGDfK) and SBrB-c(RGDfK) for $\alpha_{\mathrm{v}} \beta_{3}$ integrin was maintained. Although the reason for this finding was not elucidated, it might be because of the increased lipophilicity due to the introduction of SIB and SBrB molecules. Actually, the $\log P$ values, an index of lipophilicity, were much different between the directly labeled RGD peptides and indirectly labeled RGD peptides via SIB or SBrB (Table 1). The higher lipophilicity might cause rapid liver uptake and fast transition to the small intestine, which also could explain the low accumulation in the kidney and tumor.

We designed and prepared $\left[{ }^{125} \mathrm{I}\right] \mathrm{SIB}-\mathrm{EG}_{2}-\mathrm{c}(\mathrm{RGDfK})$ and $\left[{ }^{77} \mathrm{Br}\right] \mathrm{SBrB}-\mathrm{EG}_{2}-\mathrm{c}(\mathrm{RGDfK})$, which possess an ethylene glycol chain as a linker between the RGD peptide and SIB or SBrB to increase hydrophilicity, to improve the biodistribution of the indirectly labeled RGD peptides. $\log P$ values were significantly decreased, and the affinities for $\alpha_{\mathrm{v}} \beta_{3}$ integrin 
Table 3. Biodistribution of Radioactivity after Concomitant Intravenous Injection of ${ }^{125} \mathrm{I}-\mathrm{c}(\mathrm{RGDyK})$ and ${ }^{77} \mathrm{Br}-\mathrm{c}(\mathrm{RGDyK})$ in U87MG Tumor Bearing Mice

\begin{tabular}{|c|c|c|c|c|}
\hline \multirow{2}{*}{ Tissue } & \multicolumn{2}{|c|}{${ }^{125} \mathrm{I}-\mathrm{c}(\mathrm{RGDyK})$} & \multicolumn{2}{|c|}{${ }^{77} \mathrm{Br}-\mathrm{c}(\mathrm{RGDyK})$} \\
\hline & $1 \mathrm{~h}$ & $4 \mathrm{~h}$ & $1 \mathrm{~h}$ & $4 \mathrm{~h}$ \\
\hline Blood & $0.37(0.26)$ & $0.08(0.05)$ & $0.37(0.25)$ & $0.28(0.05)^{*}$ \\
\hline Liver & $2.88(0.54)$ & $1.29(0.22)$ & $2.57(0.48)$ & $1.48(0.34)$ \\
\hline Kidney & $9.99(2.78)$ & $5.33(1.08)$ & $10.46(2.82)^{* *}$ & $5.99(0.54)$ \\
\hline Small-intestine & $2.25(0.50)$ & $1.22(0.09)$ & $1.98(0.49)^{* *}$ & $1.24(0.13)$ \\
\hline Large-intestine & $0.81(0.22)$ & $1.95(1.27)$ & $0.73(0.19)^{*}$ & $1.76(1.16)$ \\
\hline Spleen & $2.19(0.49)$ & $1.60(0.40)$ & $1.97(0.53)^{* *}$ & $1.61(0.43)$ \\
\hline Pancreas & $0.44(0.22)$ & $0.34(0.08)$ & $0.54(0.33)$ & $0.55(0.08)^{*}$ \\
\hline Lung & $1.39(0.40)$ & $1.02(0.48)$ & $1.17(0.34)^{* *}$ & $0.94(0.21)$ \\
\hline Heart & $0.68(0.25)$ & $0.33(0.02)$ & $0.54(0.25)^{* *}$ & $0.43(0.07)$ \\
\hline Stomach $^{+}$ & $0.68(0.12)$ & $0.29(0.06)$ & $0.27(0.10)^{* *}$ & $0.33(0.08)$ \\
\hline Bone & $1.93(0.62)$ & $0.56(0.18)$ & $1.67(0.63)$ & $0.82(0.39)$ \\
\hline Muscle & $0.93(0.62)$ & $0.09(0.10)$ & $1.33(0.57)$ & $0.11(0.11)$ \\
\hline Brain & $0.08(0.02)$ & $0.04(0.00)$ & $0.07(0.01)$ & $0.12(0.00)^{* *}$ \\
\hline Tumor & $4.37(0.10)$ & $3.58(0.71)$ & $4.22(0.32)$ & $3.44(0.40)$ \\
\hline
\end{tabular}

Expressed as \% injected dose per gram. Each value represents the mean (S.D.) for four animals. ${ }^{\ddagger}$ Expressed as \% injected dose. Significance was determined using paired Student's $t$-test $\left(* p<0.05,{ }^{* *} p<0.01\right.$ vs. ${ }^{125} \mathrm{I}$-c(RGDyK)).

Table 4. Biodistribution of Radioactivity after Concomitant Intravenous Injection of $\left[{ }^{125} \mathrm{I}\right] \mathrm{SIB}-\mathrm{c}(\mathrm{RGDfK})$ and $\left[{ }^{77} \mathrm{Br}\right] \mathrm{SBrB}-\mathrm{c}(\mathrm{RGDfK})$ in U87MG Tumor Bearing Mice

\begin{tabular}{|c|c|c|c|c|}
\hline \multirow{2}{*}{ Tissue } & \multicolumn{2}{|c|}{$\left[{ }^{125}\right.$ I]SIB-c(RGDfK) } & \multicolumn{2}{|c|}{$\left[{ }^{77} \mathrm{Br}\right] \mathrm{SBrB}-\mathrm{c}(\mathrm{RGDfK})$} \\
\hline & $1 \mathrm{~h}$ & $4 \mathrm{~h}$ & $1 \mathrm{~h}$ & $4 \mathrm{~h}$ \\
\hline Blood & $0.67(0.14)$ & $0.57(0.11)$ & $0.70(0.17)$ & $0.27(0.08)$ \\
\hline Liver & $2.85(0.80)$ & $1.55(0.45)$ & $3.93(0.64)$ & $2.58(0.32)^{* *}$ \\
\hline Kidney & $2.16(0.07)$ & $1.40(0.11)$ & $1.74(0.26)^{*}$ & $1.22(0.11)^{* *}$ \\
\hline Small-intestine & $46.54(4.46)$ & $2.43(0.59)$ & $49.80(2.75)$ & $3.16(0.52)^{* *}$ \\
\hline Large-intestine & $2.90(1.64)$ & $13.03(1.69)$ & $1.91(0.67)$ & $17.08(0.84)^{*}$ \\
\hline Spleen & $1.22(0.44)$ & $0.95(0.07)$ & $1.42(0.37)$ & $1.08(0.05)$ \\
\hline Pancreas & $0.93(0.15)$ & $0.74(0.22)$ & $1.04(0.46)^{* *}$ & $0.89(0.13)$ \\
\hline Lung & $0.34(0.08)$ & $0.32(0.03)$ & $0.59(0.20)$ & $0.38(0.02)$ \\
\hline Heart & $1.03(0.13)$ & $0.80(0.24)$ & $0.80(0.14)$ & $0.68(0.09)$ \\
\hline Stomach ${ }^{\ddagger}$ & $1.03(0.10)$ & $0.71(0.14)$ & $0.67(0.09)$ & $0.63(0.05)$ \\
\hline Bone & $1.19(0.14)$ & $0.82(0.30)$ & $1.19(0.56)$ & $1.01(0.33)$ \\
\hline Muscle & $0.69(0.29)$ & $0.31(0.07)$ & $0.50(0.15)$ & $0.43(0.10)$ \\
\hline Brain & $0.13(0.01)$ & $0.14(0.03)$ & $0.56(0.04)^{* *}$ & $0.21(0.05)$ \\
\hline Tumor & $1.50(0.40)$ & $1.24(0.27)$ & $1.51(0.36)$ & $1.45(0.30)^{*}$ \\
\hline
\end{tabular}

Expressed as \% injected dose per gram. Each value represents the mean (S.D.) for four animals. ${ }^{\ddagger}$ Expressed as \% injected dose. Significance was determined using paired Student's $t$-test $(* p<0.05, * * p<0.01$ vs. [25I]SIB-c(RGDfK)).

were not attenuated by the introduction of an ethylene glycol chain, as expected. In addition, $\left[{ }^{125} \mathrm{I}\right] \mathrm{SIB}-\mathrm{EG}_{2}-\mathrm{c}$ (RGDfK) and $\left[{ }^{77} \mathrm{Br}\right] \mathrm{SBrB}-\mathrm{EG}_{2}-\mathrm{c}(\mathrm{RGDfK})$ showed similar biodistribution patterns. Contrary to our expectation, radioactivity in the liver after injection of $\left[{ }^{125} \mathrm{I}\right] \mathrm{SIB}-\mathrm{EG}_{2}-\mathrm{c}(\mathrm{RGDfK})$ and $\left[{ }^{77} \mathrm{Br}\right] \mathrm{SBrB}-\mathrm{EG}_{2}-\mathrm{c}(\mathrm{RGDfK})$ was not decreased relative to that of $\left[{ }^{125} \mathrm{I}\right] \mathrm{SIB}-\mathrm{c}(\mathrm{RGDfK})$ and $\left[{ }^{77} \mathrm{Br}\right] \mathrm{SBrB}-\mathrm{c}(\mathrm{RGDfK})$. Radioactivity in the small intestine was prominently decreased by their higher hydrophilicities; we speculate that intact tracers or radioactive metabolites moved from the liver to the intestine earlier time than $1 \mathrm{~h}$ postinjection, but tumor uptake did not improve, and the decrease of radioactivity in the intestine was insufficient. Considering the application to astatine labeling for $\alpha$-targeted therapy, which has attracted much attention because of its prominent therapeutic effects, indirect labeling methods could be useful because astatine element was not introduced into the tyrosine residue in our preliminary experiments and can be labeled indirectly using ATE. ${ }^{23)}$ Unfortunately, directly labeled RGD peptides are much better for imaging and therapy of cancer than indirectly radiohalogenlabeled RGD peptides prepared in this study. The unfavorable biodistribution of the indirectly radiohalogen-labeled RGD peptides may be because of their insufficient hydrophilicity. In fact, the introduction of the ethylene glycol chain was insufficient for increasing the hydrophilicity to the same level as that of the directly labeled RGD peptides. In our previous study, a ${ }^{67} \mathrm{Ga}-1,4,7,10$-tetraazacyclododecane-1,4,7,10-tetraacetic Acid (DOTA) complex conjugated c(RGDfK), ${ }^{67} \mathrm{Ga}-\mathrm{DOTA}-$ c(RGDfK), was evaluated. ${ }^{24)}$ Although ${ }^{67}$ Ga-DOTA-c(RGDfK) is not a radiohalogen-labeled RGD peptide, but rather a radiometal-labeled RGD peptide, ${ }^{67} \mathrm{Ga}$-DOTA-c(RGDfK) is a compound in which the $\left.{ }^{125} \mathrm{I}\right] \mathrm{SIB}$ moiety as a radiolabeling site of $\left[{ }^{125} \mathrm{I}\right] \mathrm{SIB}-\mathrm{c}$ (RGDfK) is substituted with ${ }^{67} \mathrm{Ga}$-DOTA, which has a much higher hydrophilic moiety than that of $\left[{ }^{125} \mathrm{I}\right] \mathrm{SIB}$. 
Table 5. Biodistribution of Radioactivity after Concomitant Intravenous Injection of $\left.{ }^{125} \mathrm{I}\right] \mathrm{SIB}-\mathrm{EG}_{2}-\mathrm{c}(\mathrm{RGDfK})$ and $\left[{ }^{77} \mathrm{Br}\right] \mathrm{SBrB}-\mathrm{EG}_{2}-\mathrm{c}(\mathrm{RGDfK})$ in U87MG Tumor-Bearing Mice

\begin{tabular}{|c|c|c|c|c|}
\hline \multirow{2}{*}{ Tissue } & \multicolumn{2}{|c|}{$\left[{ }^{125} \mathrm{I}\right] \mathrm{SIB}-\mathrm{EG}_{2}-\mathrm{c}(\mathrm{RGDfK})$} & \multicolumn{2}{|c|}{$\left[{ }^{77} \mathrm{Br}\right] \mathrm{SBrB}-\mathrm{EG}_{2}-\mathrm{c}(\mathrm{RGDfK})$} \\
\hline & $1 \mathrm{~h}$ & $4 \mathrm{~h}$ & $1 \mathrm{~h}$ & $4 \mathrm{~h}$ \\
\hline Blood & $1.97(0.52)$ & $1.52(0.27)$ & $1.66(0.08)$ & $1.61(0.40)$ \\
\hline Liver & $3.64(1.50)$ & $1.45(0.23)$ & $4.16(1.85)$ & $1.66(0.21)^{* *}$ \\
\hline Kidney & $2.95(0.50)$ & $1.35(0.17)$ & $3.10(0.43)$ & $1.88(0.12)^{* *}$ \\
\hline Small-intestine & $17.27(1.79)$ & $2.93(0.63)$ & $18.80(2.13)^{* *}$ & $3.21(0.63)^{*}$ \\
\hline Large-intestine & $1.22(0.55)$ & $9.28(1.20)$ & $1.04(0.40)$ & $13.08(1.61)^{* *}$ \\
\hline Spleen & $1.11(0.17)$ & $0.95(0.10)$ & $0.91(0.09)$ & $1.12(0.07)^{* *}$ \\
\hline Pancreas & $1.83(0.95)$ & $1.05(0.20)$ & $1.43(0.66)$ & $0.97(0.08)$ \\
\hline Lung & $1.89(0.65)$ & $1.38(0.17)$ & $1.49(0.09)$ & $1.81(0.11)^{*}$ \\
\hline Heart & $0.81(0.13)$ & $0.73(0.19)$ & $0.60(0.09)^{*}$ & $0.96(0.08)$ \\
\hline Stomach ${ }^{\ddagger}$ & $1.20(0.27)$ & $0.95(0.09)$ & $0.70(0.16)^{*}$ & $0.40(0.05)^{* *}$ \\
\hline Bone & $1.24(0.44)$ & $1.05(0.21)$ & $0.84(0.22)$ & $1.02(0.17)$ \\
\hline Muscle & $1.15(0.82)$ & $0.76(0.40)$ & $1.33(0.72)$ & $0.62(0.20)$ \\
\hline Brain & $0.19(0.11)$ & $0.15(0.04)$ & $0.28(0.03)$ & $0.48(0.03)^{* *}$ \\
\hline Tumor & $1.65(0.48)$ & $1.54(0.19)$ & $1.31(0.20)$ & $1.16(0.06)^{*}$ \\
\hline
\end{tabular}

Expressed as \% injected dose per gram. Each value represents the mean (S.D.) for four animals. ${ }^{\star}$ Expressed as \% injected dose. Significance was determined using paired Student's $t$-test $\left(* p<0.05, * * p<0.01\right.$ vs. $\left.\left.{ }^{[25} \mathrm{I}\right] \mathrm{SIB}-\mathrm{EG}_{2}-\mathrm{c}(\mathrm{RGDfK})\right)$.

The radioactivities (\%Dose/g) in blood, liver, kidney, small intestine, and tumor at $1 \mathrm{~h}$ postinjection of ${ }^{67} \mathrm{Ga}$-DOTA$\mathrm{c}$ (RGDfK) were $0.24 \pm 0.06,1.31 \pm 0.18,2.77 \pm 0.57,1.76 \pm 0.45$, and $3.45 \pm 0.33$, respectively, in U87MG tumor-bearing mice. The biodistribution of ${ }^{67} \mathrm{Ga}$-DOTA-c(RGDfK) was comparable or better to those of directly labeled RGD peptides. These results and the higher hydrophilicity of ${ }^{67} \mathrm{Ga}-\mathrm{DOTA}-\mathrm{c}(\mathrm{RGDfK})$ ( $\log P$ value: $-3.50 \pm 0.01)$ indicate that high hydrophilicity may be important for biodistribution of RGD peptides. Therefore, a novel labeling method using compounds with high hydrophilicity must be developed for astatine labeling of RGD peptides in the future.

\section{Conclusion}

The biodistributions of RGD peptides labeled with ATE were inadequate for tumor imaging and radionuclide therapy, even if ethylene glycol was introduced, compared with that of RGD peptides with direct labeling in tyrosine residue. For application to alpha targeted therapy using astatine labeling RGD peptide, novel labeling method must be developed in the future.

\section{Experimental}

Materials ${ }^{1} \mathrm{H}-\mathrm{NMR}$ spectra were recorded on a JEOL JNM-ECS400 spectrometer (JEOL Ltd., Tokyo, Japan), and the chemical shifts were reported in ppm downfield from an internal tetramethylsilane standard. Electrospray ionization (ESI)-MS were obtained with JEOL JMS-T100TD (JEOL Ltd.). $\left.{ }^{125} \mathrm{I}\right]$ Sodium iodide $(644 \mathrm{GBq} / \mathrm{mg})$ were purchased from PerkinElmer, Inc. (Waltham, MA, U.S.A.). ${ }^{67} \mathrm{GaCl}_{3}$ was kindly provided by Nihon Medi-physics (Tokyo, Japan). FmocLys(Boc)-OH was purchased from Merck (Darmstadt, Germany). 2-Chlorotrityl chloride resin, Fmoc-Arg(Pbf)-OH, Fmoc$\mathrm{Asp}(\mathrm{OtBu})-\mathrm{OH}$, Fmoc-Gly-OH, Fmoc-D-Tyr(tBu)-OH, and Fmoc-D-Phe-OH were purchased from Watanabe Chemical Industries, Ltd. (Hiroshima, Japan). N,N-Diisopropylethylamine (DIEA) was purchased from Nacalai Tesque (Kyoto, Japan). $N, N^{\prime}$-Diisopropylcarbodiimide (DIPC) and 1-hydroxybenzotriazole hydrate $(\mathrm{HOBt})$ were purchased from KOKUSAN
CHEMICAL Co., Ltd. (Tokyo, Japan). 1,1,1,3,3,3-Hexafluoro2-propanol (HFIP) was purchased from Tokyo Chemical Industry Co., Ltd. (Tokyo, Japan). Other reagents were of reagent grade and used as received.

Production of Bromine-77 ${ }^{77} \mathrm{Br}$ was produced in University of Fukui. Radiosynthetic isolation and purification of ${ }^{77} \mathrm{Br}$ were performed according to a previously reported method. ${ }^{22)}$ Namely, ${ }^{77} \mathrm{Br}$ was obtained from a ${ }^{77} \mathrm{Se}(\mathrm{p}, \mathrm{n})^{77} \mathrm{Br}$ reaction on an isotopically enriched $\mathrm{Cu}_{2}{ }^{77} \mathrm{Se}$-coated tungsten target with $8 \mu \mathrm{A} / 11 \mathrm{MeV}$ proton beam on a RDS Eclipse HP/RD cyclotron (Siemens, Knoxville, TN, U.S.A.).

Preparation of $\mathbf{c}($ RGDfK) and $\mathbf{c}($ RGDyK) The peptide synthesis was performed manually using a standard Fmocbased solid-phase methodology. Namely, at first, Fmoc-Gly$\mathrm{OH}$ (4 equiv.) was dissolved in dichloromethane. 2-Chlorotrityl chloride resin and DIEA (3.5 equiv.) were added. The reaction mixture was rotated for $1 \mathrm{~h}$, and $1 \mathrm{~mL}$ of methanol was added to react for another $30 \mathrm{~min}$. Next, the peptide chain was constructed in cycles of (I) $15 \mathrm{~min}$ of deprotection with $20 \%$ piperidine in dimethylformamide (DMF) and (II) $2 \mathrm{~h}$ of coupling with 2.5 eq of Fmoc-amino acid [Fmoc-Arg(Pbf)$\mathrm{OH}$, Fmoc-Lys(Boc)-OH, Fmoc-D-Phe-OH, Fmoc-D-Tyr (tBu)$\mathrm{OH}$, or Fmoc-Asp(OtBu)-OH], DIPC (2.5 equiv.) and $\mathrm{HOBt}$ (2.5 equiv.) in DMF. The coupling reaction was then repeated after Kaiser test ${ }^{25}$ was positive for the resin to obtain ResinGly-Arg(Pbf)-Lys(Boc)-D-Tyr(tBu)-Asp(OtBu)-OH or ResinGly-Arg(Pbf)-Lys(Boc)-D-Phe-Asp(OtBu)-OH. To cleave peptides from the resin, the resin-bound peptides were treated with $30 \%$ HFIP in dichloromethane for $5 \mathrm{~min}$. After filtration, the solvent in the filtrate was removed in vacuo. The residue was used in the next reaction without further purification. For cyclization of the peptides, $\mathrm{NaHCO}_{3}$ (5 equiv.) and diphenylphosphoryl azide (DPPA, 3 equiv.) were added to $5 \mathrm{~mm}$ of peptides solution in DMF. After $24 \mathrm{~h}$ stirring at room temperature, the solid $\mathrm{NaHCO}_{3}$ was removed by filtration, and DMF was removed in vacuo. The residue was used in the next reaction without further purification.

For deprotection, the cyclic peptides were treated with $95 \%$ trifluoroacetic acid (TFA), $2.5 \%$ water, and 2.5\% triisopropyl- 
<smiles>Cc1c(C)c(C)c2c(c1C)CC(C)(C)O2</smiles>

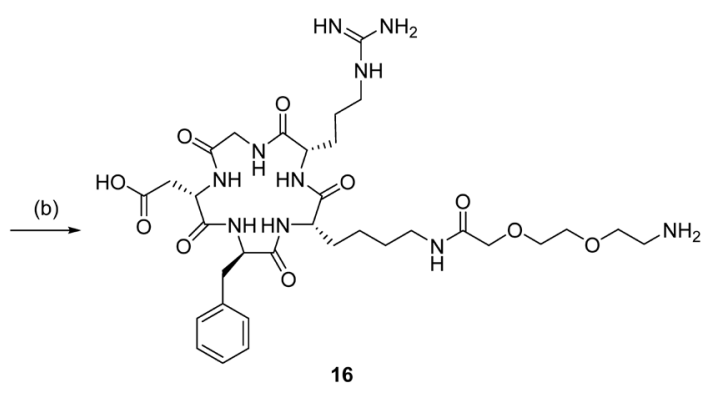

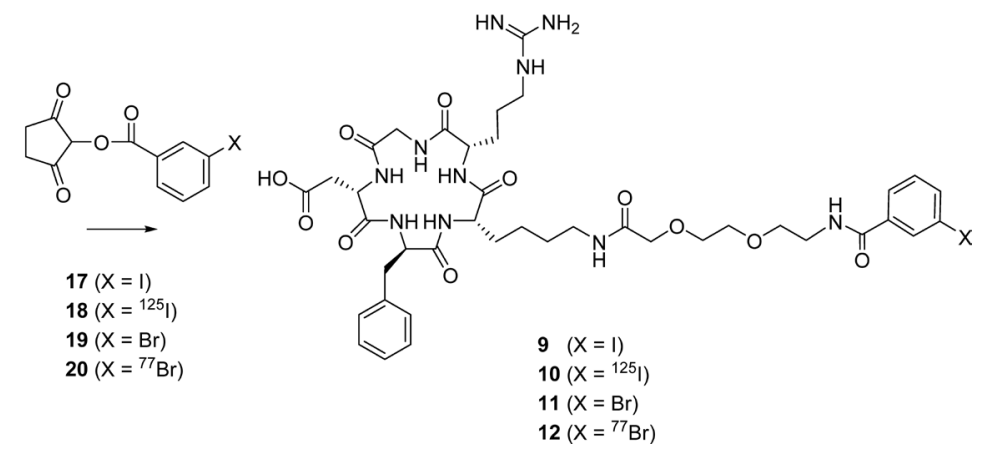

Fig. 3. Syntheses Scheme of SIB-EG -2 c(RGDfK) and $\mathrm{SBrB}_{2}-\mathrm{EG}_{2}-\mathrm{c}(\mathrm{RGDfK})$

(a) HOBt, DIPC; (b) TFA : triisopropylsilane: $\mathrm{H}_{2} \mathrm{O}(38: 1: 1)$.

silane for $24 \mathrm{~h}$ at room temperature. The crude peptide was purified by RP-HPLC performed with a Cosmosil $5 \mathrm{C}_{18}$-AR-II column $(10 \times 150 \mathrm{~mm}$; Nacalai Tesque, Kyoto, Japan) at a flow rate of $4.0 \mathrm{~mL} / \mathrm{min}$ with a gradient mobile phase of $40 \%$ methanol in water with $0.1 \%$ TFA to $60 \%$ methanol in water with $0.1 \%$ TFA for $20 \mathrm{~min}$ in the case of $\mathrm{c}(\mathrm{RGDfK})$, and with a gradient mobile phase of $15 \%$ methanol in water with $0.1 \%$ TFA to $25 \%$ methanol in water with $0.1 \%$ TFA for $20 \mathrm{~min}$ in the case of $\mathrm{c}(\mathrm{RGDyK})$. The column temperature was maintained at $40^{\circ} \mathrm{C}$. Chromatograms were obtained by monitoring the UV adsorption at a wavelength of $220 \mathrm{~nm}$. The fractions containing $\mathrm{c}(\mathrm{RGDfK})$ and $\mathrm{c}(\mathrm{RGDyK})$ were determined by mass spectrometry, and collected. The solvents were removed by lyophilization to provide c(RGDfK) $(40 \%)$ and $\mathrm{c}$ (RGDyK) $(47 \%)$ as white powders. c(RGDfK): ESI-MS $m / z: 604\left([\mathrm{M}+\mathrm{H}]^{+}\right)$. c(RGDyK): ESI-MS $m / z: 620\left([\mathrm{M}+\mathrm{H}]^{+}\right)$

Preparation of Nonradioactive I-c(RGDyK) (1) and $\mathrm{Br}$ c(RGDyK) (3) $\mathrm{NaNO}_{2}(69 \mathrm{mg}, 1.0 \mathrm{mmol})$ and $\mathrm{I}_{2}(254 \mathrm{mg}$, $1.0 \mathrm{mmol}$ ) were dissolved in $10 \mathrm{~mL}$ of $50 \%$ methanol in water. After being stirred for $30 \mathrm{~min}$ at room temperature, $130 \mu \mathrm{L}$ of this solution was taken to a microtube. c(RGDyK) $(6.2 \mathrm{mg}$, $10 \mu \mathrm{mol}$ ) was added to the solution. The reaction mixture was shaken for $2 \mathrm{~h}$ at room temperature, and purified by RP-HPLC with a Cosmosil $5 \mathrm{C}_{18}$-AR-300 $(10 \times 150 \mathrm{~mm})$ at a flow rate of $4 \mathrm{~mL} / \mathrm{min}$, the gradient mobile phase was $20 \%$ methanol in water with $0.1 \%$ TFA to $30 \%$ methanol in water with $0.1 \%$ TFA for $20 \mathrm{~min}$. The solvent was removed by lyophilization to provide I-c(RGDyK) (1) as a white powder $(2.6 \mathrm{mg}, 35 \%)$. ESIMS $m / z: 746\left([\mathrm{M}+\mathrm{H}]^{+}\right)$

c(RGDyK) $(2.4 \mathrm{mg}, 3.9 \mu \mathrm{mol})$ was dissolved in $100 \mu \mathrm{L}$ of $5 \%$ acetic acid aqueous solution, and $\mathrm{Br}_{2}$ in acetic acid and $24 \mu \mathrm{L}$ of chloramine-T aqueous solution $(2 \mathrm{mg} / \mathrm{mL})$ was added to $\mathrm{c}(\mathrm{RGDyK})$ solution. After $3 \mathrm{~h}$ of stirring at room temperature, the reaction mixture was quenched with $24 \mu \mathrm{L}$ of $\mathrm{NaHSO}_{3}$ aqueous solution $(10 \mathrm{mg} / \mathrm{mL})$ and then purified by RP-HPLC on Cosmosil $5 \mathrm{C}_{18}$-AR-II $(10 \times 150 \mathrm{~mm}$; Nacalai Tesque) at a flow rate of $4 \mathrm{~mL} / \mathrm{min}$, the isocratic mobile phase was $28 \%$ acetonitrile in water with $0.1 \%$ TFA. Chromatograms were obtained by monitoring the UV absorption at a wavelength of $220 \mathrm{~nm}$. The fractions containing Br-c(RGDyK) was determined by mass spectrometry, and collected. The solvent was removed by lyophilization to provide $\mathrm{Br}-\mathrm{c}(\mathrm{RGDyK})(\mathbf{3})$ as a white powder $(820 \mu \mathrm{g}, 30 \%)$. ESI-MS $m / z: 698\left([\mathrm{M}+\mathrm{H}]^{+}\right), 700$ $\left([\mathrm{M}+\mathrm{H}]^{+}\right)$

Preparation of Nonradioactive SIB-c(RGDfK) (5) and SBrB-c(RGDfK) (7) SIB-c(RGDfK) (5) and SBrB$c$ (RGDfK) (7) were prepared by conjugation of $c$ (RGDfK) peptide with $N$-succinimidyl 3-iodobenzoate (SIB) or $N$-succinimidyl 3-bromobenzoate (SBrB).

SIB was synthesized according to a previous report with a slight modification. ${ }^{26)}$ Namely, 3-iodobenzoic acid $(719 \mathrm{mg}$, $2.90 \mathrm{mmol}$ ) was dissolved in $10 \mathrm{~mL}$ of acetonitrile. NHydroxysuccinimide (NHS) $(401 \mathrm{mg}, 3.48 \mathrm{mmol})$ was added to the solution, and $50 \mathrm{~mL}$ of acetonitrile containing $N, N^{\prime}$ dicyclohexylcarbodiimide (DCC) $(718 \mathrm{mg}, 3.48 \mathrm{mmol})$ was added dropwise at $0^{\circ} \mathrm{C}$. The reaction mixture was stirred at room temperature for $5 \mathrm{~h}$. After filtration, the solvent in filtrate was removed in vacuo. The residue was purified by chromatography on silica gel using ethyl acetate-hexane $(1: 2)$ as the eluent to obtain SIB (742 mg, 74\%) as a white solid. ${ }^{1} \mathrm{H}-\mathrm{NMR}$ $\left(\mathrm{CDCl}_{3}\right) \delta: 2.92(4 \mathrm{H}, \mathrm{s}), 7.27(1 \mathrm{H}, \mathrm{t}, J=8.0 \mathrm{~Hz}), 8.01(1 \mathrm{H}, \mathrm{d}$, $J=7.6 \mathrm{~Hz}), 8.11(1 \mathrm{H}, \mathrm{d}, J=7.6 \mathrm{~Hz}), 8.47(1 \mathrm{H}, \mathrm{s})$.

SBrB $(68 \mathrm{mg}, 76 \%)$ was obtained as a white solid from 3-bromobenzoic acid $(60 \mathrm{mg}, 300 \mu \mathrm{mol})$ as a starting material instead of 3-iodobenzoic acid in the above-mentioned method. ${ }^{1} \mathrm{H}-\mathrm{NMR}\left(\mathrm{CDCl}_{3}\right) \delta: 2.92(4 \mathrm{H}, \mathrm{s}), 7.41(1 \mathrm{H}, \mathrm{t}, J=8.0 \mathrm{~Hz}), 7.81$ $(1 \mathrm{H}, \mathrm{d}, J=8.0 \mathrm{~Hz}), 8.07(1 \mathrm{H}, \mathrm{d}, J=7.6 \mathrm{~Hz}), 8.28(1 \mathrm{H}, \mathrm{s})$.

SIB $(5.4 \mathrm{mg}, 16.0 \mu \mathrm{mol})$ and $\mathrm{c}($ RGDfK $)(2.7 \mathrm{mg}, 4.5 \mu \mathrm{mol})$ 
were dissolved in $400 \mu \mathrm{L}$ of DMF, then $1 \mu \mathrm{L}$ of triethylamine (TEA). The mixture was shaken for $3 \mathrm{~h}$ and purified by RPHPLC on Cosmosil $5 \mathrm{C}_{18}$-AR-300 $(10 \times 150 \mathrm{~mm})$ at a flow rate of $4 \mathrm{~mL} / \mathrm{min}$, the gradient mobile phase was $40 \%$ methanol in water with $0.1 \%$ TFA to $90 \%$ methanol in water with $0.1 \%$ TFA for $20 \mathrm{~min}$. Chromatograms were obtained by monitoring the UV absorption at a wavelength of $220 \mathrm{~nm}$. The fractions containing SIB-c(RGDfK) (5) was determined by mass spectrometry, and collected. The solvent was removed by lyophilization to provide SIB-c(RGDfK) (5) as a white powder (2.2 mg, 59\%). ESI-MS m/z: $834\left([\mathrm{M}+\mathrm{H}]^{+}\right)$

$\operatorname{SBrB}(4.7 \mathrm{mg}, 16.0 \mu \mathrm{mol})$ and $\mathrm{c}($ RGDfK $)(2.4 \mathrm{mg}, 4.0 \mu \mathrm{mol})$ were reacted and purified at the above-mentioned method to obtain SBrB-c(RGDfK) (7) (1.1 mg, 35\%) as a white powder. ESI-MS $m / z: 786\left([\mathrm{M}+\mathrm{H}]^{+}\right), 788\left([\mathrm{M}+\mathrm{H}]^{+}\right)$

Preparation of Nonradioacitve SIB-EG 2 -c(RGDfK) (9) and SBrB-EG - -c(RGDfK) (11) SIB-EG $-\mathrm{c}(\mathrm{RGDfK})$ (9) and SBrB-EG $-E_{2}-c(R G D f K)$ (11) were synthesized according Fig. 3.

[2-[2-(tert-Butyloxycarbonyl)aminoethoxy]ethoxy]acetic acid (Boc-NH-EG $-\mathrm{COOH})(\mathbf{1 4})$ was prepared in 4 steps $(5 \%)$ from 2-[2-(2-chloroethoxy)ethoxy]ethanol using a method described previously. ${ }^{27)}{ }^{1} \mathrm{H}-\mathrm{NMR}\left(\mathrm{CDCl}_{3}\right) \delta: 1.44(9 \mathrm{H}, \mathrm{s}), 3.33$ $(2 \mathrm{H}, \mathrm{m}), 3.53-3.73(6 \mathrm{H}, \mathrm{m}), 4.14(2 \mathrm{H}, \mathrm{s})$. Direct analysis in real time (DART)-MS $m / z: 264\left([\mathrm{M}+\mathrm{H}]^{+}\right)$

c[Arg(Pbf)-Gly-Asp(OtBu)-D-Phe-Lys] $\quad(2.0 \mathrm{mg}, \quad 2.1 \mu \mathrm{mol})$ (13), which was synthesized using a method described previously, ${ }^{24)}$ was dissolved in $100 \mu \mathrm{L}$ of DMF. Boc-NH-EG ${ }_{2}-$ $\mathrm{COOH}$ (14) $(2.3 \mathrm{mg}, 8.6 \mu \mathrm{mol})$, HOBt $(1.2 \mathrm{mg}, 4$ equiv.), and DIPC $(1.3 \mu \mathrm{L}, 4$ equiv.) were added to the solution. After $11 \mathrm{~h}$ stirring at room temperature, the crude peptide was purified by RP-HPLC performed with a Cosmosil $5 \mathrm{C}_{18}$-AR-II column $(10 \times 150 \mathrm{~mm})$ at a flow rate of $4.0 \mathrm{~mL} / \mathrm{min}$ with a gradient mobile phase of $71 \%$ methanol in water with $0.1 \%$ TFA to $97 \%$ methanol in water with $0.1 \%$ TFA for $18 \mathrm{~min}$. The column temperature was maintained at $40^{\circ} \mathrm{C}$. Chromatograms were obtained by monitoring the UV adsorption at a wavelength of $220 \mathrm{~nm}$. The fraction containing Boc-NH-EG 2 -c $[\operatorname{Arg}(\mathrm{Pbf})-$ Gly-Asp(OtBu)-D-Phe-Lys] (15) was determined by mass spectrometry, and collected. The solvent was removed by lyophilization to provide compound $\mathbf{1 5}(29 \%)$ as a white powder. Boc-NH-EG ${ }_{2}-\mathrm{c}[\mathrm{Arg}(\mathrm{Pbf})-\mathrm{Gly}-\mathrm{Asp}(\mathrm{OtBu})-\mathrm{D}-\mathrm{Phe}-\mathrm{Lys}]$ (3): ESIMS $m / z: 1158\left([\mathrm{M}+\mathrm{H}]^{+}\right)$

For deprotection of functional groups, compound 15 was treated with a mixture of $95 \%$ TFA, $2.5 \%$ water, and $2.5 \%$ triisopropylsilane for $2 \mathrm{~h}$ at room temperature. The crude peptide was purified by RP-HPLC performed with a Cosmosil $5 \mathrm{C}_{18}$ AR-II column $(10 \times 150 \mathrm{~mm})$ at a flow rate of $4.0 \mathrm{~mL} / \mathrm{min}$ with a gradient mobile phase of $20 \%$ methanol in water with $0.1 \%$ TFA to $56 \%$ methanol in water with $0.1 \%$ TFA for $18 \mathrm{~min}$. The fraction containing $\mathrm{NH}_{2}-\mathrm{EG}_{2}-\mathrm{c}(\mathrm{RGDfK})$ (16) was determined by mass spectrometry, and collected. The solvent was removed by lyophilization to provide compound $16(50 \%)$ as a white powder. $\mathrm{NH}_{2}-\mathrm{EG}_{2}$-c(RGDfK) (16): ESI-MS m/z: 749 $\left([\mathrm{M}+\mathrm{H}]^{+}\right)$

Compound $16(200 \mu \mathrm{g}, 0.41 \mu \mathrm{mol})$ was dissolved in $100 \mu \mathrm{L}$ of DMF. SIB $(370 \mu \mathrm{g}, 1.09 \mu \mathrm{mol})(\mathbf{1 7})$, which was synthesized as above-mentioned, and $1.0 \mu \mathrm{L}$ of TEA were added to the reaction mixture. After stirring for $2 \mathrm{~h}$ at room temperature, the crude compound 9 was purified by RP-HPLC performed with a Cosmosil $5 \mathrm{C}_{18}$-AR-II column $(4.6 \times 150 \mathrm{~mm})$ at a flow rate of $1.0 \mathrm{~mL} / \mathrm{min}$ with a gradient mobile phase of $20 \%$ aceto- nitrile in water with $0.1 \%$ TFA to $60 \%$ acetonitrile in water with $0.1 \%$ TFA for $20 \mathrm{~min}$. The fraction containing SIB-EG ${ }_{2}$ c(RGDfK) (9) was determined by mass spectrometry, and collected. The solvent was removed by lyophilization to provide compound $9(170 \mu \mathrm{g}, 64 \%)$ as a white powder. ESI-MS $m / z$ : $979\left([\mathrm{M}+\mathrm{H}]^{+}\right)$

SBrB-EG 2 -c(RGDfK) (63\%) (11) was obtained as a white powder using SBrB (19) instead of SIB (17) in the above-mentioned method. ESI-MS $m / z$ : $931\left([\mathrm{M}+\mathrm{H}]^{+}\right), 933\left([\mathrm{M}+\mathrm{H}]^{+}\right)$

Preparation of ${ }^{125} \mathrm{I}-\mathrm{c}(\mathrm{RGDyK})$ (2) and ${ }^{77} \mathrm{Br}-\mathrm{c}(\mathrm{RGDyK})$ (4) $\mathrm{c}(\mathrm{RGDyK})$ was labeled with ${ }^{125} \mathrm{I}$ using the chloramine-T method. ${ }^{28)}$ Briefly, $\left[{ }^{125} \mathrm{I}\right]$ sodium iodide solution $(3.7 \mathrm{MBq} / 1 \mu \mathrm{L})$ was added to $\mathrm{c}(\mathrm{RGDyK})$ in $100 \mu \mathrm{L}$ of $0.1 \mathrm{M}$ phosphate buffered saline (PBS) pH $7.4(1 \mathrm{mg} / \mathrm{mL})$. Following mixing, $10 \mu \mathrm{L}$ of chloramine-T aqueous solution $(1 \mathrm{mg} / \mathrm{mL})$ was added. After $5 \mathrm{~min}$ of standing at room temperature, the reaction mixture was quenched with $10 \mu \mathrm{L}$ of $\mathrm{Na}_{2} \mathrm{H}_{2} \mathrm{SO}_{5}$ solution $(10 \mathrm{mg} / \mathrm{mL})$ in $0.1 \mathrm{M}$ acetate buffer $\mathrm{pH} 6.8$ and then purified by RP-HPLC on Cosmosil $5 \mathrm{C}_{18}$-AR-II $(4.6 \times 150 \mathrm{~mm})$ at a flow rate of $1 \mathrm{~mL} / \mathrm{min}$. The gradient mobile phase was $20 \%$ methanol in water with $0.1 \%$ TFA to $30 \%$ methanol in water with $0.1 \%$ TFA for $20 \mathrm{~min}$.

${ }^{77} \mathrm{Br}-\mathrm{c}(\mathrm{RGDyK})$ was prepared by a similar method as preparation of ${ }^{125} \mathrm{I}-\mathrm{c}(\mathrm{RGDyK}) .{ }^{77} \mathrm{Br}^{-}(3.7 \mathrm{MBq})$ in water was added to $100 \mu \mathrm{L}$ of $0.1 \mathrm{M}$ acetate buffer $\mathrm{pH} 6.8$ containing $100 \mu \mathrm{g}$ of $\mathrm{c}(\mathrm{RGDyK})$, and then $10 \mu \mathrm{L}$ of chloramine-T aqueous solution $(1 \mathrm{mg} / \mathrm{mL})$ was added. After $5 \mathrm{~min}$ standing at room temperature, the reaction mixture was quenched with $10 \mu \mathrm{L}$ of $\mathrm{Na}_{2} \mathrm{~S}_{2} \mathrm{O}_{5}$ solution $(10 \mathrm{mg} / \mathrm{mL})$ and then purified by RP-HPLC using the above-mentioned method.

Preparation of $\left[{ }^{125}\right.$ I]SIB-c(RGDfK) (6) $N$-Succinimidyl ester of 3-(tri- $n$-butylstannyl)benzoate (ATE) $(0.5 \mathrm{mg})$, which was synthesized using a method reported previously with a slight modification from 3-broobenzoic acid via a fourstep, ${ }^{18,29)}$ was dissolved in $79 \mu \mathrm{L}$ of ethanol. Fifteen microliter of chloramine-T $(1 \mathrm{mg} / \mathrm{mL})$ in ethanol, $21 \mu \mathrm{L}$ of $1 \%$ acetic acid in ethanol, and $\left[{ }^{125} \mathrm{I}\right] \mathrm{NaI}(3.7 \mathrm{MBq})$ were added to the ATE solution. After standing at room temperature for $10 \mathrm{~min}$, $\left[{ }^{125} \mathrm{I}\right] \mathrm{SIB}$ (18) was purified by RP-HPLC on Cosmosil $5 \mathrm{C}_{18^{-}}$ AR-II $(4.6 \times 150 \mathrm{~mm})$ at a flow rate of $1 \mathrm{~mL} / \mathrm{min}$. The gradient mobile phase was $50 \%$ methanol in water with $0.1 \%$ TFA to $70 \%$ methanol in water with $0.1 \%$ TFA for $20 \mathrm{~min}$. Fractions containing $\left[{ }^{125} \mathrm{I}\right] \mathrm{SIB}$ (18) was collected, and the solvent was dried by $\mathrm{N}_{2}$ gas. $\left.{ }^{125} \mathrm{I}\right] \mathrm{SIB}$ (18) was dissolved in $50 \mu \mathrm{L}$ of DMF, and $50 \mu \mathrm{g}$ of $\mathrm{c}$ (RGDfK) and $0.5 \mu \mathrm{L}$ of TEA were added to the $\left[{ }^{125} \mathrm{I}\right] \mathrm{SIB}$ (18) solution. The mixture solution was incubated for $40 \mathrm{~min}$ at room temperature, and purified by RP-HPLC on Cosmosil $5 \mathrm{C}_{18}$-AR-II $(4.6 \times 150 \mathrm{~mm})$ at a flow rate of $1 \mathrm{~mL} / \mathrm{min}$. The gradient mobile phase was $40 \%$ methanol in water with $0.1 \%$ TFA to $90 \%$ methanol in water with $0.1 \%$ TFA for $20 \mathrm{~min}$.

Preparation of $\left[{ }^{77} \mathbf{B r}\right]$ SBrB-c(RGDfK) (8) ATE (0.5 mg) was dissolved in $55 \mu \mathrm{L}$ of ethanol. Fifteen microliter of chloramine- $\mathrm{T}(1 \mathrm{mg} / \mathrm{mL})$ in ethanol, $21 \mu \mathrm{L}$ of $1 \%$ acetic acid in ethanol, and ${ }^{77} \mathrm{Br}^{-}$(3.7 MBq) was added to the ATE solution. The reaction mixture stood at room temperature for $10 \mathrm{~min}$. After purification of $\left[{ }^{77} \mathrm{Br}\right] \mathrm{SBrB}$ (20) by RP-HPLC, conjugation of $\left[{ }^{77} \mathrm{Br}\right] \mathrm{SBrB}(\mathbf{2 0})$ with $\mathrm{c}(\mathrm{RGDfK})$ were performed by the same manner as above-mentioned to obtain $\left[{ }^{77} \mathrm{Br}\right] \mathrm{SBrB}-\mathrm{c}(\mathrm{RGDfK})$ (8).

Preparation of $\left[{ }^{125} \mathrm{I}\right] \mathrm{SIB}-\mathrm{EG}_{2}$-c(RGDfK) (10) and $\left[{ }^{77} \mathrm{Br}\right]-$ 
SBrB-EG $-\mathbf{c}$ (RGDfK) (12) $\quad\left[{ }^{125} \mathrm{I}\right] \mathrm{SIB}-\mathrm{EG}_{2}-\mathrm{c}(\mathrm{RGDfK}) \quad$ (10) and $\left[{ }^{77} \mathrm{Br}\right] \mathrm{SBrB}-\mathrm{EG}_{2}-\mathrm{c}(\mathrm{RGDfK})$ (12) were prepared by conjugation of $\left[{ }^{125} \mathrm{I}\right] \mathrm{SIB}(\mathbf{1 8})$ and $\left[{ }^{77} \mathrm{Br}\right] \mathrm{SBrB}$ (20), respectively, with $\mathrm{NH}_{2}-\mathrm{EG}_{2}-\mathrm{c}(\mathrm{RGDfK})$ (16) using same method as abovementioned.

Determination of Partition Coefficient The partition coefficients of ${ }^{125} \mathrm{I}-\mathrm{c}(\mathrm{RGDyK}) \quad$ (2), ${ }^{77} \mathrm{Br}-\mathrm{c}(\mathrm{RGDyK})$ (4), $\quad\left[{ }^{125} \mathrm{I}\right] \mathrm{SIB}-\mathrm{c}(\mathrm{RGDfK}) \quad$ (6), $\quad\left[{ }^{77} \mathrm{Br}\right] \mathrm{SBrB}-\mathrm{c}(\mathrm{RGDfK}) \quad$ (8), $\left[{ }^{125} \mathrm{I}\right] \mathrm{SIB}-\mathrm{EG}_{2}-\mathrm{c}(\mathrm{RGDfK}) \quad(\mathbf{1 0}), \quad\left[{ }^{77} \mathrm{Br}\right] \mathrm{SBrB}-\mathrm{EG}_{2}-\mathrm{c}(\mathrm{RGDfK})$ (12), and ${ }^{67} \mathrm{Ga}-\mathrm{DOTA}-\mathrm{c}(\mathrm{RGDfK})$, which was prepared according to the method reported previously, as a reference compound, ${ }^{24)}$ were measured as described previously. ${ }^{30)}$ The partition coefficient was determined by calculating the ratio of $\mathrm{cpm} / \mathrm{mL}$ in 1-octanol to that in the $0.1 \mathrm{M}$ phosphate buffer $\mathrm{pH}$ 7.4, and expressed as a common $\operatorname{logarithm}(\log P)$.

$\boldsymbol{\alpha}_{\mathbf{v}} \boldsymbol{\beta}_{3}$ Integrin Binding Assay The affinities of Ic(RGDyK) (1), Br-c(RGDyK) (3), SIB-c(RGDfK) (5), SBrB-c(RGDfK) (7), SIB-EG - -c(RGDfK) (9), and SBrB$\mathrm{EG}_{2}-\mathrm{c}(\mathrm{RGDfK})$ (11) for $\alpha_{\mathrm{v}} \beta_{3}$ integrin were evaluated by competitive inhibition between the each peptide and ${ }^{125} \mathrm{I}$ $\mathrm{c}(\mathrm{RGDyK})$ to $\alpha_{\mathrm{v}} \beta_{3}$ integrin according to procedures reported previously. ${ }^{24)}$

The $\mathrm{IC}_{50}$ values of the peptides were calculated by curve fitting with nonlinear regression using GraphPad Prism 5.04 (GraphPad Software Inc., San Diego, CA, U.S.A.). Each data point is the average of four determinations, and $\mathrm{IC}_{50}$ values were expressed as the mean \pm standard deviation (S.D.) from independent three experiments.

Biodistribution Experiments of ${ }^{125} \mathrm{I}-\mathrm{c}(\mathrm{RGDyK})$ (2) ${ }^{77} \mathrm{Br}-\mathrm{c}(\mathrm{RGDyK})$ (4), [ $\left.{ }^{125} \mathrm{I}\right] \mathrm{SIB}-\mathrm{c}(\mathrm{RGDfK})$ (6), $\left[{ }^{77} \mathrm{Br}\right] \mathrm{SBrB}-$ c(RGDfK) (8), [ $\left.{ }^{125} \mathrm{I}\right] \mathrm{SIB}-\mathrm{EG}_{2}$-c(RGDfK) (10), and $\left[{ }^{77} \mathrm{Br}\right]-$ SBrB-EG ${ }_{2}$-c(RGDfK) (12) in Tumor-Bearing Mice Experiments with animals were conducted in strict accordance with the Guidelines for the Care and Use of Laboratory Animals of Kanazawa University. The animal experimental protocols used were approved by the Committee on Animal Experimentation of Kanazawa University. The animals were housed with free access to food and water at $23^{\circ} \mathrm{C}$ with a $12-\mathrm{h}$ alternating light/dark schedule. U87MG glioblastoma cell line was obtained from DS Pharma Biomedical (Osaka, Japan). To produce tumors, approximately $5 \times 10^{6}$ of the prepared U87MG glioblastoma cells in $100 \mu \mathrm{L}$ of medium were injected subcutaneously into the right shoulder of 4-week-old female BALB/c nude mice (15-19g, Japan SLC, Inc., Hamamatsu, Japan). Biodistribution experiments were performed approximately 14-21 d postinoculation, i.e., the time needed for tumors to reach a palpable size. A mixed solution of ${ }^{125} \mathrm{I}-\mathrm{c}(\mathrm{RGDyK})$ (2) $(40 \mathrm{kBq})$ and ${ }^{77} \mathrm{Br}-\mathrm{c}(\mathrm{RGDyK})(4)(56 \mathrm{kBq})$, a mixed solution of $\left[{ }^{125} \mathrm{I}\right] \mathrm{SIB}-\mathrm{c}(\mathrm{RGDfK})(6)(17 \mathrm{kBq})$ and $\left[{ }^{77} \mathrm{Br}\right] \mathrm{SBrB}-\mathrm{c}(\mathrm{RGDfK})$ (8) $(27 \mathrm{kBq})$, or a mixed solution of $\left[{ }^{125} \mathrm{I}\right] \mathrm{SIB}-\mathrm{EG}_{2}-\mathrm{c}(\mathrm{RGDfK})$ (10) $(14 \mathrm{kBq})$ and $\left[{ }^{77} \mathrm{Br}\right] \mathrm{SBrB}-\mathrm{EG}_{2}$-c(RGDfK) (12) $(15 \mathrm{kBq})$ was intravenously administered to groups of four mice. Mice were sacrificed at 1 and $4 \mathrm{~h}$ postinjection. Tissues of interest were removed and weighed, and radioactivity counts of ${ }^{125} \mathrm{I}$ and ${ }^{77} \mathrm{Br}$ were determined with an auto well gamma counter (AccuFLEX $\gamma$ ARC-8001 Hitachi, Ltd., Tokyo, Japan) and corrected for background radiation. A window from 16 to 71 $\mathrm{keV}$ was used for counting ${ }^{125} \mathrm{I}$ and a window from 95 and 700 $\mathrm{keV}$ was used for counting for ${ }^{77} \mathrm{Br}$. When the radioactivity of ${ }^{77} \mathrm{Br}$ was measured, the crossover of ${ }^{125} \mathrm{I}$ activity into the ${ }^{77} \mathrm{Br}$ channel was negligible. More than one month after the experi- ments, ${ }^{125}$ I activity was determined because the radioactivity of ${ }^{77} \mathrm{Br}$ was negligible at that time. The radioactivity counts of ${ }^{125} \mathrm{I}$ were measured after attenuation of ${ }^{77} \mathrm{Br}$.

Statistical Evaluation $\mathrm{IC}_{50}$ values in integrin binding assays among I-c(RGDyK), Br-c(RGDyK), SIB-c(RGDfK), SBrB-c(RGDfK), SIB-EG ${ }_{2}-\mathrm{c}(\mathrm{RGDfK}), \quad$ and $\quad \mathrm{SBrB}_{-}-\mathrm{EG}_{2}-$ c(RGDfK) was determined using a one-way ANOVA followed by the Tukey-Kramer post hoc test. Significance between the biodistribution data of ${ }^{125}$ I-labeled peptides and the corresponding ${ }^{77} \mathrm{Br}$-labeled peptides was determined using paired Student's $t$-test. Results were considered statistically significant at $p<0.05$.

Conflict of Interest The authors declare no conflict of interest.

\section{References}

1) Brooks P. C., Montgomery A. M., Rosenfeld M., Reisfeld R. A., Hu T., Klier G., Cheresh D. A., Cell, 79, 1157-1164 (1994).

2) Brooks P. C., Clark R. A., Cheresh D. A., Science, 264, 569-571 (1994).

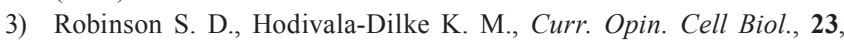
630-637 (2011).

4) Brooks P. C., Eur. J. Cancer, 32A, 2423-2429 (1996).

5) Niu G., Chen X., Theranostics, 1, 30-47 (2011).

6) Haubner R., Wester H. J., Reuning U., Senekowitsch-Schmidtke R., Diefenbach B., Kessler H., Stocklin G., Schwaiger M., J. Nucl. Med., 40, 1061-1071 (1999).

7) Meyer A., Auernheimer J., Modlinger A., Kessler H., Curr. Pharm. Des., 12, 2723-2747 (2006).

8) Schottelius M., Laufer B., Kessler H., Wester H. J., Acc. Chem. Res., 42, 969-980 (2009).

9) Janssen M. L., Oyen W. J., Dijkgraaf I., Massuger L. F., Frielink C., Edwards D. S., Rajopadhye M., Boonstra H., Corstens F. H., Boerman O. C., Cancer Res., 62, 6146-6151 (2002).

10) Beer A. J., Haubner R., Goebel M., Luderschmidt S., Spilker M. E., Wester H. J., Weber W. A., Schwaiger M., J. Nucl. Med., 46, 1333-1341 (2005).

11) Yoshimoto M., Ogawa K., Washiyama K., Shikano N., Mori H., Amano R., Kawai K., Int. J. Cancer, 123, 709-715 (2008).

12) Chen H., Niu G., Wu H., Chen X., Theranostics, 6, 78-92 (2016).

13) Ogawa M., Hatano K., Oishi S., Kawasumi Y., Fujii N., Kawaguchi M., Doi R., Imamura M., Yamamoto M., Ajito K., Mukai T., Saji H., Ito K., Nucl. Med. Biol., 30, 1-9 (2003).

14) Ogawa K., Masuda R., Shiba K., Bunseki Kagaku, 66, 403-411 (2017)

15) Ogawa K., Kanbara H., Shiba K., Kitamura Y., Kozaka T., Kiwada T., Odani A., EJNMMI Res., 2, 54 (2012).

16) Loot A. E., van Buiten A., Roks A. J., Henning R. H., J. Pharmacol. Toxicol. Methods, 51, 51-55 (2005).

17) Ogawa K., Shiba K., Akhter N., Yoshimoto M., Washiyama K., Kinuya S., Kawai K., Mori H., Cancer Sci., 100, 2188-2192 (2009).

18) Zalutsky M. R., Narula A. S., Int. J. Rad. Appl. Instrum. [A], 38, 1051-1055 (1987).

19) Zalutsky M. R., Narula A. S., Cancer Res., 48, 1446-1450 (1988).

20) Schirrmacher R., Wangler B., Bailey J., Bernard-Gauthier V., Schirrmacher E., Wangler C., Semin. Nucl. Med., 47, 474-492 (2017).

21) Sundin J., Tolmachev V., Koziorowski J., Carlsson J., Lundqvist H., Welt S., Larson S., Sundin A., Nucl. Med. Biol., 26, 923-929 (1999).

22) Ogawa K., Kanbara H., Kiyono Y., Kitamura Y., Kiwada T., Kozaka T., Kitamura M., Mori T., Shiba K., Odani A., Nucl. Med. Biol., 40, 445-450 (2013).

23) Zalutsky M. R., Vaidyanathan G., Curr. Pharm. Des., 6, 1433-1455 (2000)

24) Ogawa K., Yu J., Ishizaki A., Yokokawa M., Kitamura M., Kitamu- 
ra Y., Shiba K., Odani A., Bioconjug. Chem., 26, 1561-1570 (2015).

25) Kaiser E., Colescott R. L., Bossinger C. D., Cook P. I., Anal. Biochem., 34, 595-598 (1970).

26) Effendi N., Ogawa K., Mishiro K., Takarada T., Yamada D., Kitamura Y., Shiba K., Maeda T., Odani A., Bioorg. Med. Chem., 25, 5576-5585 (2017).

27) Clavé G., Boutal H., Hoang A., Perraut F., Volland H., Renard P. Y., Romieu A., Org. Biomol. Chem., 6, 3065-3078 (2008).
28) Wilbur D. S., Hadley S. W., Grant L. M., Hylarides M. D., Bioconjug. Chem., 2, 111-116 (1991).

29) Arano Y., Wakisaka K., Ohmomo Y., Uezono T., Mukai T., Motonari H., Shiono H., Sakahara H., Konishi J., Tanaka C., Yokoyama A., J. Med. Chem., 37, 2609-2618 (1994).

30) Ogawa K., Mukai T., Arano Y., Otaka A., Ueda M., Uehara T., Magata Y., Hashimoto K., Saji H., Nucl. Med. Biol., 33, 513-520 (2006). 